\title{
Behaviorism: Some truths that need telling, some errors that need correcting
}

\author{
PHILIP HOWARD GRAY \\ Montana State University, Bozeman, Montana 59717
}

\begin{abstract}
The assumptions that collectively constitute behaviorism are described. All had been proposed and defended before Watson coined his famous term for them. J. B. Watson was to blame for much of the confusion surrounding behaviorism because he embraced a metaphysical framework that had nothing to do with behaviorism. A sample of criticisms of behaviorism is evaluated.
\end{abstract}

Behaviorism is the logic supporting a science of behavior. It is not in any manner deficient, nor is there anything morally deviant about it. It is merely the summation of assumptions necessary for an experimental science, but how such a metaphysically complex individual as John Broadus Watson came to be the major spokesman for this is not understood and is in many ways tragic, for almost immediately after his initial paper on behaviorism, Watson muddled the meaning of the term by applying it to viewpoints on provenance and values that were actually antithetical to the science of behavior itself (J. B. Watson, 1913a, 1913b, 1916a, 1916c).

In order to examine what J. B. Watson's critics have been doing wrong, it is important to elucidate what he did wrong, but before that, it is mandatory to define behaviorism, of which there is only one kind, the plethora of adjectives to the contrary notwithstanding.

\section{THE ASSUMPTIONS OF BEHAVIORISM}

When I was a graduate student, I set myself the task of extracting from the history of psychology and philosophy the assumptions and pioneer research that would account for the development of behaviorism. The assumptions that interested me were bipolar, evidently created so by actions and reactions on the part of intellectuals. They are related to the "prescriptions" of the historian R. I. Watson (1967), but curiously, there is little overlap.

The first assumption was the humanism that started in the Renaissance, being basically the belief that man is a part of nature and can be studied for his own sake without obligatory reference to divinism (Gray, 1967).

The second assumption was determinism, as opposed to indeterminism. This is not, however, the determinism that supposes human events to be "completely explicable in terms of antecedents" (R. I. Watson, 1967). That kind of determinism was accepted by the Puritan magistrates when they judged a rash of afflictions in Salem Village to have witchcraft practices as antecedents (Caporael, 1976). Scientific determinism, which is what we are here concerned about, is the position that cause and effect relationships are consistently repeatable and are never displaced or broken by outside forces such as magic, miracles, or "freedom of will" (Gray, 1969).

The third assumption is objectivism, as opposed to rationalism; it is the insistence that behavioral facts like other scientific facts must be arrived at via observations and experiments, that the principles and laws of behavior cannot be presupposed simply because they seem supposable (Boring, 1950; Gray, 1962; R. I. Watson, 1967).

The fourth assumption is phyletic realism, as opposed to idealism, meaning that humans and animals are believed to act according to principles that may be compared, and long before J. B. Watson had won the right to make such comparisons in psychology, others had won it outside (Gray, 1968-1969, 1973). It is missing from the prescriptive analysis of R. I. Watson (1967).

The fifth and final assumption is psychological materialism, as opposed to all the varieties of antimaterialism ever created by the genius of man who has, seemingly like Boring's (1957) robot, been programmed to argue that he is not a robot. As a prescription, it also is missing from the aforementioned prescriptive analysis (R. I. Watson, 1967), which means that anybody using that analysis can never get at the core of the behaviorism controversy.

Every science has its materialism; there is no science that does not. Psychological materialism is the assertion that the causal energies of events studied are to be found within the investigative frame . ork, not outside. This means that mentation cannot be accepted as a causal system because it has no force that can be specified or measured. Skinner (1963) has pointed out that if psychology were the science of mental life, then it would have developed and defended a special methodology, which it has not done. Pelletier (1978) has made a reasonably good case for why a mental program should be commenced, but he cannot tell us how to commence it. Ornstein (1977) makes many optimistic statements about the mind, but the only scientific data he presents come from other fields of investigation.

Skinner (1963) is correct. But why is he correct? The 
reason seems to be that a research methodology cannot be developed without a materialism, and materialism excludes mental life from scientific research. Perhaps we have here an antinomy the philosophers never saw: Mental psychology can be a science when it has developed a scientific materialism, but psychological materialism relegates mental events to correlative status. The many enthusiastic appeals for mental science that appear in American Psychologist, of which Lieberman (1979) is a recent example, merely confirm that more and more of the frogs in the millpond electing to fly does not mean they will fly.

In the historical sense, these assumptions are all there is to behaviorism. J. B. Watson invented none of them, for he surely got the concept of psychological materialism from Douglas Spalding via William James (see Gray, 1968b). Yet I do not mean to detract from Watson's contribution, for it was his insight, knowledge, vigor, and superb writing style that gathered all of this under one romantic name: behaviorism.

\section{WATSON'S METAPHYSICS}

John Broadus Watson, named for the evangelical preacher John Broadus, was more than a simple behaviorist. Had he been just that, he would have been the most consequential of psychology's pioneers. But he was instead the most complicated, and in many ways the most pernicious, personality psychology ever produced.

What made him so complicated was his metaphysics, which went beyond the description of behaviorism and included such antiscientific presuppositions as peripheralism, reductionism, social control, and environmentalism. Although these had nothing to do with behaviorism, at different times in his career, Watson espoused all of them under that rubric.

Peripheralism is the doctrine that neural fibers are merely convenient conductors of stimuli and that, although the brain transmits, it does not alter, multiply, or initiate impulses. Learning does not need to depend upon neurological development because it is as likely to occur at the periphery of the body, in the muscles or glands themselves, in the connections between effectors and neurons, or even in the kinesthetic system. There is not the slightest doubt that Watson took his doctoral research problem in peripheralism (J. B. Watson, 1903) from his physiology teacher, Jacques Loeb, although the dissertation was supervised by psychologists because James Angell and John Dewey, both scions of old colonial families, considered the German-Jewish immigrant Loeb to be not "safe" as the young Watson's dissertation sponsor (J. B. Watson, 1936). The later bizarre attempt to locate language in peripheral mechanisms has to be understood in light of Watson's early addiction to the beliefs of Loeb (J. B. Watson, 1920).

Reductionism is the attitude that knowledge about an area of science can be explained by some set of principles and that these principles, if not the knowledge itself, are finite. It was Watson's affinity for this type of thinking, which can likely be traced to Loeb, that led him to seek a unitary principle of action that he found in the conditioned reflex (J. B. Watson, 1916b).

The aim of social control is to regulate a science, art, or discipline for the good of the people. In our society, this ambition is often traced to Karl Marx. When the time comes to ascertain if and how Marx could have influenced Watson, we will first look to George Sylvester Morris, the Hegalian scholar whose devoted student was John Dewey, who himself stoutly believed in the social import and responsibility of the intelligentsia (Hofstadter, 1955). The early use of the word "control" in Watson's lexicon need be no more than the determinist trying to achieve full control of research variables. But after his second marriage, Watson became a social control advocate. The title of the book promoting this policy was ironic, for it had just about nothing to do with behaviorism, although it did give that legitimate endeavor a bad reputation (J. B. Watson, 1930).

Environmentalism is the total rejection of the influence of heredity upon behavior. While probably all psychologists are familiar with Watson's environmentalism, few are likely to notice that it is more than the empiricism that Watson would have heard from his many WASP teachers, but it includes aspects of the peculiar conception of behavioral ontogeny in terms of environmental fields of force that Loeb brought from Germany to the University of Chicago. When cognizant of both influences upon Watson, we can account for his rejection of instinct and heredity that characterized his system in later years (J. B. Watson, 1926), even though in earlier parts of his career Watson did excellent field work on animal instinct (Gray, 1968a).

We can be sure that no psychologist except Watson ever possessed such a curious admixture of determinism, environmentalism, realism, materialism, reductionism, objectivism, and peripheralism, as well as the crusading spirit of science twisted to social control. Small wonder that Watson has been a problem for the historians of psychology. That they are even able to deal with his announcement of behaviorism is probably due to the fact that they need only quote his remarkably lucid paper (J. B. Watson, 1913a). Beyond that, they founder on the shoals of his complexity.

Until the historians adequately consider Watson's metaphysics, he will remain an enigma to them. But an enigma is one thing; reluctance to follow established rules of scholarship is another.

\section{MISCONCEPTIONS AND MISINFORMATION}

In the space remaining, I intend to sample the range of complaints against behaviorism, hoping that by pointing out some errors and fallacies I will stimulate, if not a spirit of reform among the older critics, at least a modicum of carefulness among the younger ones. 
In a recent book, Robinson (1976) says that many have been attracted to behaviorism because it is free of the difficulties suffered by psychological materialisms. This is not only incorrect, but it shows a substantial ignorance of what other scholars have done. Robinson has written an intellectual history of psychology, but he apparently does not consider it worthwhile to consult the learned periodicals in which many articles critical to an intellectual history are published. Even when historians do use journals, they miss much when dealing with behaviorism. For example, Marx and Hillix (1973) do not have the term peripheralism in their index, and they seem wholly unaware of this controversy in the history of behaviorism.

In the same manner of not knowing what happened, Lorenz (1950) says that if Watson had only once reared a wild bird by hand he would not have held the simple view of behavior that he did. Actually, Watson reared many wild birds by hand (Gray, 1963, 1968a; J. B. Watson, 1908).

Miller (1962) says that if Watson had not been so inept as a philosopher he might have offered behaviorism as a pragmatic theory of mind. Fortunately for us, Watson had had enough philosophy courses to know that he could do no such thing. In another inversion, Dewsbury (1973) tells us that Watson adopted a position of extreme parsimony and environmentalism: environmentalism, yes; extreme parsimony, no. Environmentalism, with its emphasis on learning, cannot be a parsimonious position. Learning is always treated as the experimental hypothesis. The null hypothesis, as Beach (1955) noted in his serendipitous attack on the instinct concept, has to be considered the equivalent of the innate, although only in initial experiments, as I have amended (Gray, 1966). Thus, the assumption that a behavior is caused by innate factors is really the parsimonious course of action, since it is equivalent to the null hypothesis. Environmentalism assumes that one has already gone ahead and done an experiment to overturn the null hypothesis, when no such thing has really happened. Environmentalism is bad science.

Behaviorism has set the occasion for many emotional displays. R. I. Watson (1963, p. 375) says of the behaviorist. "It was as if to him the mental was outside this rational world of ours, dwelling in the dark with the other ghosts and goblins." Perhaps Krech's (1968) statement that behaviorism is one of the greatest catastrophes to have befallen psychology is more hyperbole than hysteria, but it nonetheless conveys an attitude irreconcilable with science. Arthur Koestler (cited in Miller, 1964) continually rails at behaviorism, sometimes startling other antibehaviorists. Koch's (1964) overwhelming hostility toward behaviorism is indicated by his remark that he would be happy to say what the Rice Symposium participants were hearing could be characterized as the death rattle of behaviorism, but that would be a more dignified statement than he would like to sponsor, because death is, at least, a dignified process.

Although the period immediately following Watson's emergence saw a number of disparate endeavors being called this and that kind of behaviorism, the strangest reduction of the term to empty meaninglessness was done by Kantor (1968), who takes us on a tour of archaic behaviorism, antibehaviorism, prebehaviorism, protobehaviorism, Watsonian behaviorism, authentic behaviorism, interbehaviorism, and field behaviorism, with Watson's type being a tentative and preliminary version of naturalistic psychology. However, surely the oddest analysis of Watson was that of Bergmann (1956, p. 267) who said, "Watson's particular mistake was that in order to establish that there are no interacting minds, which is true, he thought it necessary to assert that there are no minds, which is not only false but silly." I have seen just about everything Watson published, and I never encountered anything close to what Bergmann says he asserted. Watson was not stupid, he was not insane, and he took more philosophy than probably any of his critics, so I do not accept that he asserted, believed, or hinted that there are no minds. On the same grounds, one rejects the canard by
Ornstein $(1977$, p. 7) that "It was sometimes jokingly said of John Watson that he thought no one conscious save himself."

I will finish this sampling by noting that Day (1969) has sought a reconciliation between behaviorism and phenomenology, which is impossible. With the possible exception of humanism, phenomenology is diametrically opposed to the assumptions that make behaviorism possible.

The most that behaviorism has ever asked is that others understand the need of the behaviorist for precision in the logical discussions of the study of behavior, along with the right to study behavior. Behaviorism acknowledges mind and consciousness as concepts in the verbal community and merely points to the truism that mental events have never been proven to be causative upon behavior, only correlative. Behaviorism, wryly put, is good scientific thinking. There is nothing in behaviorism to warrant the teratogeny of its misinformed and misinforming detractors.

\section{REFERENCES}

BeAch, F. A. The descent of instinct. Psychological Review, $1955,62,401-410$.

Bergmann, G. The contribution of John B. Watson. Psychological Review, 1956, 63, 265-276.

Boring, E. G. A history of experimental psychology (2nd ed.). New York: Appleton-Century-Crofts, 1950.

Boring, E. G. When is human behavior predetermined? Scientific Monthly, 1957, 84, 189-196.

Caporae L, L. R. Ergotism: The Satan loosed in Salem? Science, 1976, 192, 21-26.

DAY, W. F. Radical behaviorism in reconciliation with phenomenology. Journal of the Experimental Analysis of Behavior, $1969,12,315-328$.

Dewsbury, D. A. Introduction. In D. A. Dewsbury \& D. A. Rethlingshafer (Eds.), Comparative psychology. New York: McGraw-Hill, 1973.

Gray, P. H. Douglas Alexander Spalding: The first experimental behaviorist. Journal of General Psychology, 1962, 67, 299-307.

Gray, P. H. The descriptive study of imprinting in birds from 1873 to 1953. Journal of General Psychology, 1963, 68, 333-346.

Gray, P. H. The comparative analysis of behavior. Dubuque, Iowa: Brown, 1966.

Gray, P. H. The nature of man or man's place in nature? Bruno, Spinoza, and La Mettrie. Journal of General Psychology, 1967, 76, 183-192.

GraY, P. H. John Broadus Watson, ethologist. XII Congres International d'Histoire des Sciences, 1968, pp. 31-33. (a)

Gray, P. H. Prerequisite to an analysis of behaviorism: The conscious automaton theory from Spalding to William James. Journal of the History of the Behavioral Sciences, 1968, 4, 365-376. (b)

Gray, P. H. The early animal behaviorists: Prolegomenon to ethology. Isis, 1968-1969, 59, 372-383.

Gray, P. H. The problem of free will in a scientific universe: Rene Descartes to John Tyndall. Journal of General Psychology, $1969,80,57-72$.

Gray, P. H. Comparative psychology and ethology: A saga of twins reared apart. Annals of the New York Academy of Sciences, 1973, 223, 49-53.

Hofstadte R, R. Social Darwinism in American thought (2nd ed.). Boston: Beacon Press, 1955.

Kantor, J. R. Behaviorism in the history of psychology. Psychological Record, 1968, 18, 151-166.

Косн, S. Comments of Professor Koch on Norman Malcolm's behaviorism as a philosopy. In T. W. Wann (Ed.), Behaviorism and phenomenology. Chicago: University of Chicago Press, 1964.

Krech, D. Assault on the citadel. Science, 1968, 160, 649-650. Lieberman, D. A. Behaviorism and the mind: A (limited) call 
for a return to introspection. American Psychologist, 1979 , 34, 319-333.

LoRENZ, K. Z. The comparative method in studying innate behaviour patterns. In Symposia of the Society for Experimental Biology, Physiological mechanisms in animal behaviour. Cambridge, England: Cambridge University Press, 1950.

Marx, M. H., \& Hillix, W. A. Systems and theories in psychology (2nd ed.). New York: McGraw-Hill, 1973.

Mille , G. A. Psychology, the science of mental life. New York: Harper \& Row, 1962.

Mille R, G. A. Review of Koestler's The act of creation. Scientific American, 1964, 211(5), 145-149.

Ornstein, R. E. The psychology of consciousness (2nd ed.). New York: Harcourt, Brace, Jovanovich, 1977.

Pelletie R, K. R. Towards a science of consciousness. New York: Delacorte, 1978.

RoBinson, D. N. An intellectual history of psychology. New York: Macmillan, 1976.

Skinner, B. F. Behaviorism at fifty. Science, 1963, 140, 951-958.

W Atson, J. B. Animal education-The psychical development of the white rat. Chicago: University of Chicago Press, 1903.

W. ATson, J. B. The behavior of noddy and sooty terns. Carnegie Institute of Washington Publications, 1908, 103, 187-255.

WAtson, J. B. Image and affection in behavior. Journal of Philosophy, Psychology, and Scientific Method, 1913, 10, 421-428. (a)

Watson, J. B. Psychology as the behaviorist views it. Psychological Review, 1913, 20, 158-177. (b)

WAtson, J. B. Behavior and the concept of mental disease.
Journal of Philosophy, Psychology, and Scientific Method, 1916, 13, 589-597. (a)

WATSON, J. B. The place of the conditioned-reflex in psychology. Psychological Review, 1916, 23, 89-116. (b)

Watson, J. B. The psychology of wish fulfillment. Scientific Monthly, 1916, 3, 479-487. (c)

WATSON, J. B. Is thinking merely the action of language mechanisms? British Journal of Psychology, 1920, 11, 87-104.

Watson, J. B. What the nursery has to say about our instincts. In C. Murchison (Ed.), Psychologies of 1925. Worcester, Mass: Clark University Press, 1926.

Watson, J. B. Behaviorism (2nd ed.). New York: Norton, 1930. Watson, J. B. Autobiography. In C. Murchison (Ed.), A history of psychology in autobiography (Vol. 3). Worcester, Mass: Clark University Press, 1936.

Watson, R. I. The great psychologists from Aristotle to Freud. Philadelphia: Lippincott, 1963.

Watson, R. I. Psychology: A prescriptive science. American Psychologist, 1967, 22, 435-443.

\section{NOTE}

The ideas, opinions, and criticisms in this paper have previously been presented at the 79th Annual Convention of the American Psychological Association and at the 143rd National Meeting of the American Association for the Advancement of Science.

(Received for publication February 11, 1980.) 